\title{
The Effect of Amino Acids and Sulfur Compounds on the Utili- zation of Non-Protein Nitrogen by Rumen Microorganisms in Vitro, with Special Remark to L-Methionine
}

\author{
Fumio Takahashi, Masao Kametaka and Makoto Kandatsu* \\ Department of Animal Science, Faculty of Agriculture, \\ The University of Tokyo, Tokyo 113
}

(Received September 5, 1973)

\begin{abstract}
In a series of in vitro experiments, the effects of amino acids and sulfur compounds, especially L-methionine, on the utilization of non-protein nitrogen (NPN) by rumen microorganisms were studied. Incubation media used in this study consisted of $10 \mathrm{~m} l$ of strained rumen fluid, $30 \mathrm{~m} l$ of the mineral solution and $0.6 \mathrm{~g}$ of corn starch as a basal medium with various nitrogen and sulfur sources added. The results obtained are summarized below. (1) The amount of microbial protein synthesized during 6 hours of incubation was greater in the tube with amino acid mixture (control) than that in any of the other tubes from which a certain group of amino acids was removed. When sulfur-containing amino acids were removed, the amount was significantly less $(P<0.05)$ compared with the control. (2) Of the twelve amino acids tested, only $L$-methionine significantly $(P<0.05)$ increased the utilization of urea. These results suggest that L-methionine is one of the most important nutritional factors influencing the utilization of NPN by rumen microorganisms. (3) A negligible or negative effect of L-methionine on microbial protein synthesis was found when casein or an amino acid mixture was supplied to the medium as the sole source of nitrogen. (4) At 6 hours of incubation the amount of microbial protein in the tube with $\mathrm{L}$-methionine was higher $(\mathrm{P}<0.05)$ than that in the tube with $\mathrm{K}_{2} \mathrm{SO}_{4}$ as sulfur sources. (5) The effect of L-methionine on rumen bacterial protein synthesis was also observed.
\end{abstract}

Several workers have reported that the ruminant can be maintained in a positive nitrogen balance for more than a year on purified diets containing urea and ammonium salt as the sources of nitrogen and that all the amino acids are synthesized in the rumen by microorganisms $\left.{ }^{1}{ }^{2}\right)$. However, it seems possible that certain amino acids are needed for rumen microorganisms since several important species of rumen bacteria are known to require these amino acids for growth. The authors' previous paper ${ }^{3)}$ also indicated that the greatest amount of microbial protein was synthesized when both urea and the amino acid mixture were supplied to the medium as the nitrogen sources in vitro.

Since urea is essentially devoid of sulfur, some benefits have been demonstrated in ruminants by adding sulfur-containing amino acids or inorganic sulfur compounds to purified diets low in sulfur and having a part or all of the protein replaced by urea.

Although a large number of investigations on the effect of certain amino acids or sulfur compounds on the utilization of NPN have been made intensively in vivo-10), few works have been performed in attempt to define the effects of these compounds on the utilization of NPN by rumen microorganisms in vitro.

\footnotetext{
* Present address: Azabu Veterinary College.
} 


\section{Utilization of NPN by Rumen Microorganisms}

The purpose of this study including the previous paper ${ }^{9 /}$ is to elucidate the effect of various nutritional factors influencing the utilization of NPN compounds such as urea. The present paper consists of two parts. Firstly, the effect of various groups of amino acids on microbial protein synthesis was investigated. Secondly, the effect of L-methionine on the utilization of urea as compared with various sulfur compounds such as $\mathrm{K}_{2} \mathrm{SO}_{4}$ was studied.

\section{Experimental procedure}

The technique of incubation and the composition of a mineral solution and an amino acid mixture were the same as those reported in the previous paper ${ }^{31}$. The amount of microbial protein synthesized was determined by calculating the difference between the amounts of microbial protein- $N$ present in the tube contents before and after the incubation. Ammonia$\mathrm{N}$, total-VFAs and microbial protein were determined by the same method as those reported in the previous paper ${ }^{3)}$.

In order to investigate the effect of the removal of certain amino acids from the amino acid mixture on microbial protein synthesis, amino acids were divided into seven groups according to their chemical properties.

1) Methionine, Cysteine; sulfur-containing amino acids.

2) Tryptphan, Proline; heterocyclic amino acids.

3) Phenylalanine, Tyrosine; aromatic amino acids.

4) Valine, Leucine, Isoleucine; branched chain amino acids.

5) Glutamic acid, Aspartic acid; acidic amino acids.

6) Arginine, Lysine, Histidine; basic amino acids.

7) Glycine, Alanine, Serine, Threonine; the other amino acids.

A male goat weighing $25 \mathrm{~kg}$ was defaunated by the following treatment in order to obtain rumen contents without protozoa. Defaunation was completed by adding $3 \mathrm{~g}$ of dioctyl sodium sulfosuccinate per day for five consecutive days according to the procedure used by Abou AkKad et al. ${ }^{11}$. When extreme care is taken to keep the animal isolated, it has been possible to maintain the animal in a protozoa-free condition for at least 2 months.

\section{Results and disccusion}

The effect of the removal of certain amino acids from the amino acid mixture ${ }^{3 \prime}$ on the amount of microbial protein synthesized is shown in Table 1. The amount of microbial protein synthesized in the tube with the amino acid mixture (control) during 6 hours of incubation was greater than that in any of the other tubes in which certain groups of amino acids were removed. Especially when sulfur-containing amino acids such as methionine and cysteine were removed, the amount of microbial protein synthesized was significantly less $(P<0.05)$ than that of the control.

When one half of amino acid- $\mathrm{N}$ was replaced by urea- $\mathrm{N}$, no difference in the amount of microbial protein synthesized was found among the tubes except the tube without sulfurcontaining amino acids.

Fig. 1 shows the effect of supplemental amino acids on the utilization of urea.

No supplemental effect was found in the tubes except the tube with L-methionine. There are two possible explanations for this poor effect of the supplemental amino acids except the L-methionine on microbial protein synthesis. 
Table 1. Effect of removal of certain amino acids from complete amino acid mixture on microbial protein sy nthesis

\begin{tabular}{|c|c|c|}
\hline & \multicolumn{2}{|c|}{$\begin{array}{l}\% \text { microbial protein synthesis as compared } \\
\text { with complete amino acid mixture }\end{array}$} \\
\hline & Trial $1^{a}$ & Trial $2^{b)}$ \\
\hline $\begin{array}{l}\text { Amino acid mixture } \\
\text { (control) }\end{array}$ & 100.0 & 100.0 \\
\hline $\begin{array}{l}\text { Methionine } \\
\text { Cysteine }\end{array}$ & $72.2 \pm 5.3^{*}$ & $82.8 \pm 5.7^{*}$ \\
\hline $\begin{array}{l}\text { Tryptphan } \\
\text { Proline }\end{array}$ & $83.6 \pm 6.4$ & $95.2 \pm 4.8$ \\
\hline $\begin{array}{l}\text { Phenylalanine } \\
\text { Tyrosine }\end{array}$ & $90.4 \pm 5.4$ & $95.7 \pm 4.7$ \\
\hline $\begin{array}{l}\text { Valine, Leucine } \\
\text { Isoleucine }\end{array}$ & $89.1 \pm 4.7$ & $94.9 \pm 4.3$ \\
\hline $\begin{array}{l}\text { Glutamic acid } \\
\text { Aspartic acid }\end{array}$ & $93.7 \pm 4.9$ & $95.8 \pm 3.9$ \\
\hline $\begin{array}{l}\text { Arginine, Lysine } \\
\text { Histidine }\end{array}$ & $85.3 \pm 5.8$ & $95.7 \pm 4.7$ \\
\hline $\begin{array}{l}\text { Glycine, Alanine } \\
\text { Serine, Threonine }\end{array}$ & $93.2 \pm 3.9$ & $96.0 \pm 3.7$ \\
\hline
\end{tabular}

a) Amino acids (14 $\mathrm{mg} \mathrm{N}$ ) were supplied to each medium as the nitrogen source.

b) Amino acids $(7 \mathrm{mg} \mathrm{N})$ and urea $(7 \mathrm{mg} \mathrm{N})$ were suppled to each medium as the nitrogen sources.

c) Composition of amino acid mixture is the same as that reported in the previous paper's?.

d) The amount of amino acid-N added was equal in each tube. The amount of methionine and cysteine- $\mathrm{N}$ was replaced by an equal amount of amino acid mixture- $\mathrm{N}$ without methionine and cysteine.

Each value represents mean \pm S.E. of triplicate tubes.

* Significantly $(\mathrm{P}<0.05)$ different from control

One is that the amino acids added may have been too readily available in the medium and were rapidly catabolized instead of being incorporated into microbial protein. The other is the possibility that these amino acids did not function as limiting factors in the microbial protein synthesis.

On the other hand, the significant $(\mathrm{P}<0.05)$ increase in microbial protein synthesis was found in the tube with $\mathrm{L}$-methionine as compared with the other amino acids.

Many workers have reported the effect of DL-methionine on the utilization of dietary urea in vivo ${ }^{8,12,18)}$. Nitrogen balance studies have shown that adding methionine to a ration containing urea increased retention of absorbed $\mathrm{N}$ by lambs ${ }^{4}$

However, there are few in vitro studies concerning the effect of $L$-methionine on the utilization of NPN by rumen microorganisms. PATTON $e t$ al. ${ }^{14}$ reported that increased microbial lipid biosynthesis was obtained when methionine was added to rumen fluid incubated in vitro, and they suggested that methionine may be a limiting factor in the nutrition of certain rumen microorganisms, particularly some protozoa.

Furthermore, Bacteroides numinicola has a nutritional requirement for methionine when grown with ammonia as a major nitrogen source ${ }^{15)}$, and a measurable portion of radioactivity added as methionine-methyl- ${ }^{14} \mathrm{C}$ appeared to be incorporated into microbial protein, rapidly at first then at a slower rate in 10 hours of incubation ${ }^{16}$. 


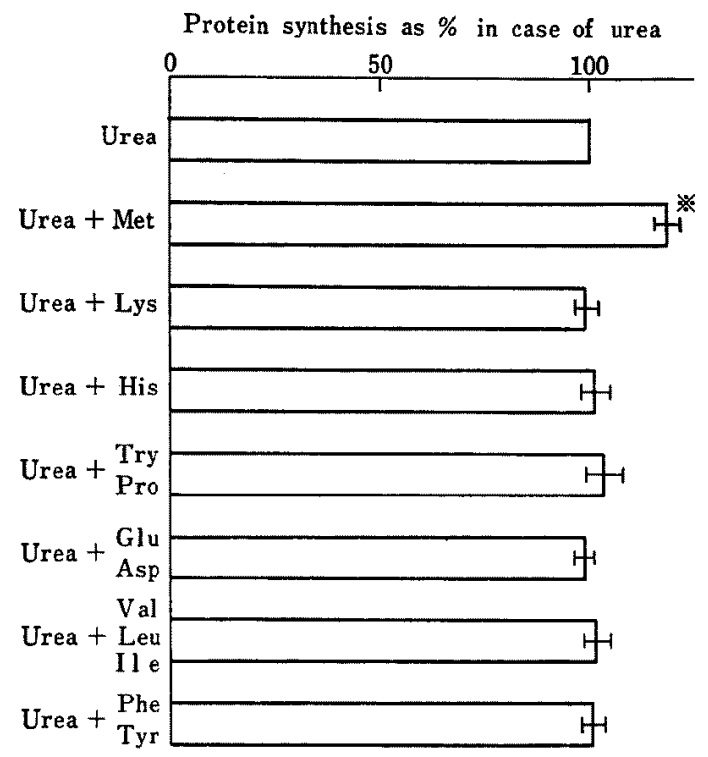

Fig. 1. Effect of supplemental amino acids on the utilization of urea for 6 hours incubation.

Nitrogen source: Urea ( $15 \mathrm{mg} \mathrm{N})$ and amino acids $(0.5 \mathrm{mg} \mathrm{N})$. Each value represents mean $\pm \mathrm{S}$. E. of triplicate tubes.

* Significantly $(\mathrm{P}<0.05)$ different from urea.

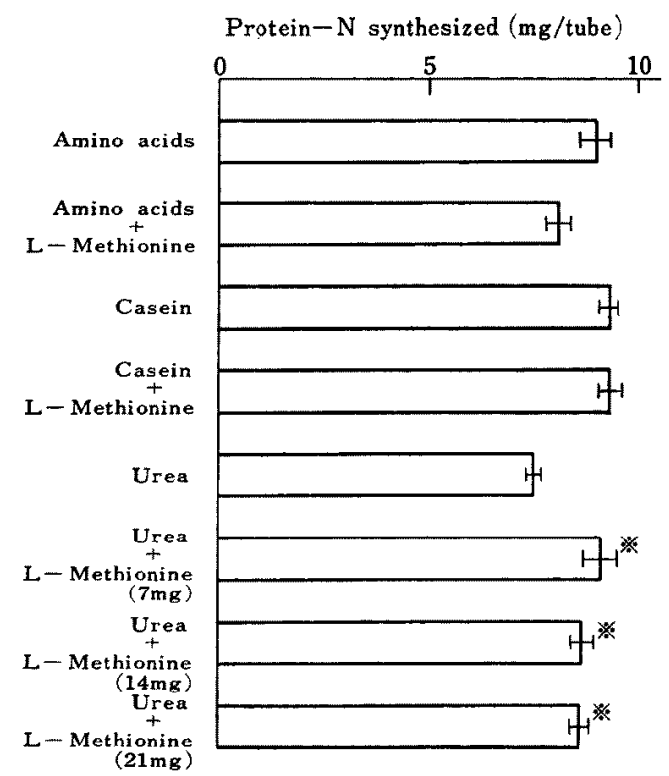

Fig. 2. Effect of L-methionine on microbial protein synthesis when complete amino acid mixture, casein or urea were supplied to the medium as nitrogen sources (15 mg N).

Each value represents mean $\pm S$. E. of triplicate tubes.

* Significantly $(\mathrm{P}<0.05)$ different from urea. 
These results suggest that $\mathrm{L}$-methionine is one of the most important nutritional factors influencing the utilization of NPN and microbial protein synthesis.

In order to elucidate this effect in detail, the effect of L-methionine on microbial protein synthesis when amino acid mixture, casein, or urea was supplied to the medium as the nitrogen sources has been investigated.

Fig. 2 shows that the effect of L-methionine supplementation is dependent on nitrogen source in the medium. In the case of amino acid mixture or casein, there was no effect of L-methionine supplementation on the amount of microbial protein synthesized. Lack of response to the $\mathrm{L}$-methionine supplementation is attributed to the fact that the amino acid mixture and casein added contained about $4 \mathrm{mg}$ of $\mathrm{L}$-methionine per tube and this level of L-methionine was sufficient for microbial protein synthesis under these conditions. On the contrary, the addition of $7 \mathrm{mg} \mathrm{L}$-methionine significantly $(\mathbf{P}<0.05)$ increased the amount of microbial protein when urea was supplied to the medium as a nitrogen source. However, there was no further increase of microbial protein synthesis when the amount of $L$-methionine added was raised to $14 \mathrm{mg}$ or $21 \mathrm{mg}$ per tube.

Data in Table 2 show the effect of L-methionine on microbial protein and DNA synthesis, and on total-VFAs production as compared with $\mathrm{K}_{2} \mathrm{SO}_{4}$. The amount of microbial protein and DNA synthesized and total-VFAs produced increased with time of incubation. At 6 hours the amount of protein and total-VFAs in the tube with $\mathrm{L}$-methionine was greater $(\mathbf{P}<0.05)$ than that in the tube with $\mathrm{K}_{2} \mathrm{SO}_{4}$ as the sole sulfur source. It is easily understood that the amount

Table 2. Effect of L-methionine on microbial protein and DNA synthesis and total-VFAs production

\begin{tabular}{llcccc}
\hline & & 0 hour & 4 hour & 6 hour & 8 hour \\
\hline Protein-N & $\mathrm{K}_{2} \mathrm{SO}_{4}$ & $7.00 \pm 0.09$ & $9.52 \pm 0.21$ & $12.04 \pm 0.43$ & $17.64 \pm 1.12$ \\
$(\mathrm{mg} /$ tube) & $\mathrm{K}_{2} \mathrm{SO}_{4}+\mathrm{Met}$ & $7.00 \pm 0.09$ & $9.94 \pm 0.32$ & $13.86 \pm 0.45 *$ & $18.05 \pm 0.98$ \\
$\mathrm{DNA}$ & $\mathrm{K}_{2} \mathrm{SO}_{4}$ & $0.96 \pm 0.02$ & $1.51 \pm 0.06$ & $2.06 \pm 0.13$ & $2.14 \pm 0.15$ \\
$(\mathrm{mg} /$ tube $)$ & $\mathrm{K}_{2} \mathrm{SO}_{4}+\mathrm{Met}$ & $0.96 \pm 0.02$ & $1.61 \pm 0.08$ & $2.18 \pm 0.11$ & $2.24 \pm 0.19$ \\
Total-VFAs & $\mathrm{K}_{2} \mathrm{SO}_{4}$ & $1.12 \pm 0.08$ & $1.57 \pm 0.11$ & $2.74 \pm 0.24$ & $3.00 \pm 0.29$ \\
(m mole/tube) & $\mathrm{K}_{2} \mathrm{SO}_{4}+$ Met & $1.12 \pm 0.08$ & $1.65 \pm 0.09$ & $2.93 \pm 0.22^{*}$ & $3.46 \pm 0.21^{*}$ \\
\hline
\end{tabular}

Each value represents mean \pm S.E. of triplicate tubes.

Nitrogen and sulfur source: Urea (15 mg N) and $\mathrm{K}_{2} \mathrm{SO}_{4}(1.5 \mathrm{mg} \mathrm{S})$ or $\mathrm{K}_{2} \mathrm{SO}_{4}(1 \mathrm{mg} \mathrm{S})+$ L-methionine $(0.5 \mathrm{mg} \mathrm{S})$

* Significantly $(\mathrm{P}<0.05)$ different from $\mathrm{K}_{2} \mathrm{SO}_{4}$

Table 3. Effect of various sulfur compounds on the utilization of urea

\begin{tabular}{lcccc}
\hline & \multicolumn{4}{c}{ Protein-N (mg/tube) } \\
\hline L-methionine & 0 hour & 3 hour & 6 hour & 9 hour \\
L-cysteine & $12.24 \pm 0.38$ & $14.05 \pm 0.55$ & $20.23 \pm 0.29^{\mathrm{a}}$ & $21.28 \pm 0.35^{\mathrm{e}}$ \\
$\mathrm{K}_{2} \mathrm{SO}_{4}$ & $12.24 \pm 0.38$ & $13.51 \pm 0.32$ & $19.04 \pm 0.31^{\mathrm{b}}$ & $19.95 \pm 0.41^{\mathrm{f}}$ \\
$\mathrm{Na}_{2} \mathrm{~S}$ & $12.24 \pm 0.38$ & $14.03 \pm 0.35$ & $19.11 \pm 0.24^{\mathrm{b}}$ & $21.07 \pm 0.32^{\mathrm{e}}$ \\
$\mathrm{No}$ sulfur & $12.24 \pm 0.38$ & $13.35 \pm 0.42$ & $17.22 \pm 0.33^{\mathrm{c}}$ & $17.25 \pm 0.42^{\mathrm{s}}$ \\
& $12.24 \pm 0.38$ & $12.96 \pm 0.22$ & $14.74 \pm 0.27^{\mathrm{d}}$ & $15.76 \pm 0.45^{\mathrm{b}}$ \\
\hline
\end{tabular}

Nitrogen and sulfur source: Urea (15 $\mathrm{mg} \mathrm{N}$ ) and various sulfur compounds (1.5 mg S). Each value represents mean \pm S.E. of triplicate tubes.

a $\sim \mathrm{h}$ : Values bearing different superscript letters differ significantly from each other $(\mathrm{P}<0.05)$ 
of total-VFAs produced inceases with the increasing of the amount of microbial protein synthesized as an index to microbial growth.

STARKS et $a .^{8}{ }^{8}$ reported that there was no statistically significant difference in weight gains and wool growth among the sulfur sources within elemental sulfur, sodium sulfate and DL-methionine. The effect of various sulfur sources on the utilization of urea by rumen microorganisms is shown in Table 3. After 3 hours of incubation, no difference in the amount of microbial protein was found among the tubes. After 6 hours of incubation, however, the amount of microbial protein in the tube with $\mathrm{L}$-methionine was greater than that in any other tubes. At 9 hours, the amount of microbial protein in the tube with $\mathrm{L}$-methionine was almost the same as that in the tube with $\mathrm{K}_{2} \mathrm{SO}_{4}$.

The ability of rumen microorganisms to incorporate inorganic sulfate-S into cysteine or methionine was suggested by Loose et al. ${ }^{11}$ and demonstrated by BLock and STEKoL ${ }^{17}$ through the use of radioactive sodium sulfate. They tentatively described the conversion of inorganic sulfur to cysteine or methionine by rumen microorganisms as follows;

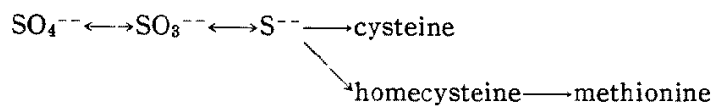

These results may suggest that in the earlier part of incubation the conversion to methionine from cysteine or sulfate by microorganisms did not occur sufficiently and the conversion rate may be a limiting factor in microbial protein synthesis. Another possible explanation for the superiority of L-methionine over other sulfur compounds tested concerns the effectiveness of $\mathrm{L}$-methionine on rumen protozoa. At the 9 th hour of incubation, the concentration of protozoa was $9.2 \times 10^{5}$ per $\mathrm{m} l$ of medium in the tube with $\mathrm{L}$-methionine and $6.0 \times 10^{5}$ in the tube with $\mathrm{K}_{2} \mathrm{SO}_{4}$. These results support the fact that methionine hydroxy analog significantly increased the concentration of protozoa in the sheep ${ }^{18)}$.

One explanation for the inferiority of cysteine may be considered due to the fact that cysteine is more rapidly degraded than methionine by rumen microorganisms.

NADER and WALKER ${ }^{18)}$ reported that when cysteine or methionine labeled with both S-35 and C-14 was incubated with rumen fluid, a larger proportion of S-35 and C-14 appeared in the sulfide pool and in volatile fatty acids in the tube with cysteine than in the tube with methionine.

The amount of microbial protein in the tube with $\mathrm{Na}_{2} \mathrm{~S}$ was the least anong those in the tubes with any other sulfur sources tested. This result suggests that availability of sulfide as a sulfur souce is inferior to other sulfur compounds such as sulfate or Lmethionine.

Fig. 3 shows the effect of L-methionine on rumen bacterial protein synthesis and the utilization of urea with rumen fluid from a defaunated goat. The amount of bacterial protein increased with the time of incubation and doubled after 6 hours of incubation. At 6 hours the amount of bacterial protein in the tube with L-methionine was significantly higher $(\mathrm{P}<0.05)$ than that in the tube with $\mathrm{K}_{2} \mathrm{SO}_{4}$ as the sulfur source. This result suggests the direct effect of $\mathrm{L}$-methionine on rumen bacterial protein synthesis. The concentration of ammonia- $\mathrm{N}$ had a maximum value at 2 hours of incubation and then gradually decreased in the two tubes. From time course changes in the rate of protein synthesis and ammonia production, it is evident that a large portion of ammonia produced is rapidly incorporated into bacterial protein. 


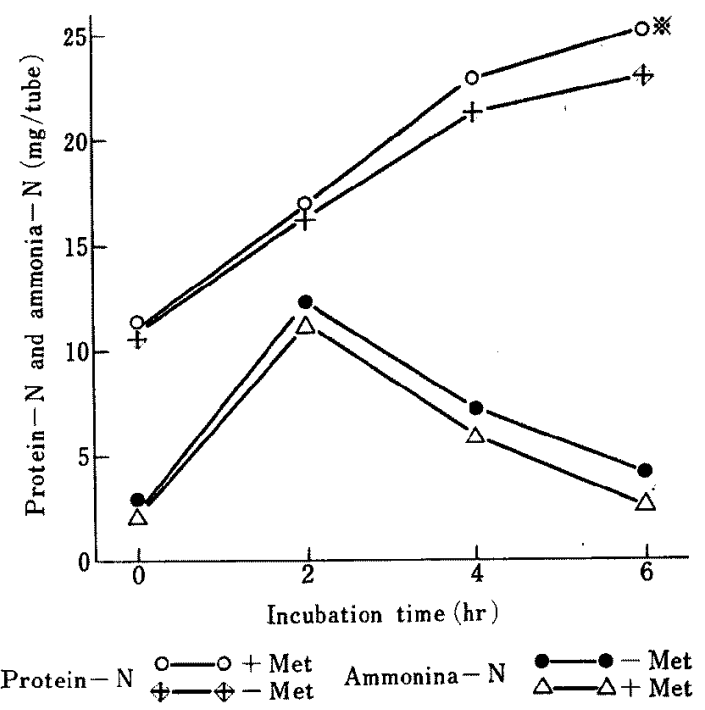

Fig. 3. Effect of L-methionine on bacterial protein synthesis. Rumen fluidfrom a defaunated goat. Nitrogen and sulfur source: Urea (15 mg N) and $\mathrm{K}_{2} \mathrm{SO}_{4}$ or $\mathrm{K}_{2} \mathrm{SO}_{4}+\mathrm{L}$-methionine (1.5 mg S).

Each value represents mean of triplicate tubes.

* Significantly $(P<0.05)$ different from $\mathrm{K}_{2} \mathrm{SO}_{4}$.

From the present results, it can be concluded that $\mathrm{L}$-methionine is one of the most important nutritional factors influencing the utilization of NPN compounds such as urea by rumen microorganisms.

\section{References}

1) Loosli, J. K., H.H. Williams, W.E. Thomas, F.H. Ferris, and L. A. Maynard, Science 110: $144-145.1949$.

2) Virtanen, A. A., Science 153: 1603-1614. 1966.

3) Takahashi, F., M. Kametaka, and M. Kandatsu, Jap J Zootech Sci 45: 157-164. 1974.

4) Mclaren, G. A., G.C. Anderson, and K.M. Barth, J Anim Sci 24: 231-234. 1965.

5) Bunn, C.R., J. J. McNeil, and G. Matron, J Nutr 94: 47-51. 1968.

6) Oltjen, R.R., J.D. Robbins, and R.E. Davis, J Anim Sci 23: 767-770. 1964.

7) Clifford, A. J., J.R. Bourdette, and A.D. Tiliman, J Anim Sci 24: 1081-1084. 1968.

8) Starks, P.B., W.G. Hale, U.G. Garrigus, R.M. Forbes, and M.F. James, J Anim Sci 13: 249-257. 1954.

9) Oltjen, R.R., R. J. Sirny, and A.D. Tillman, J Anim Sci 21: 277-283. 1962.

10) Hume, I. D., and P.R. Bird, Aust J Agric Res 21: 315-322. 1970.

11) Agou Akkada, A.R., E.E. Bartley, R. Berube, L. R. Fina, R. M. Meyer, D. Henricks, and F. Julius, Appl Microbiol 16: 1475-1477. 1968.

12) Gossett, W.H., T.W. Perry, M. T. Mohler, M.P. Plumlee, and W.M. Beeson, J Anim Sci 21: 248-251, 1962.

13) Steinacker, G., T. J. Devlin, and J.R. Ingalis, Can J Anim Sci 50: 319-324. 1970.

14) Patton, R.A., R.D. McCarthy, and L.C. Griel, Jr., J Dairy Sci 53: 460-465. 1970.

15) Pittman, K. A., and M.P. Bryant, J Bacteriol 88: 401-410. 1964.

16) Salsbury, R.L., D. K. Marvil, C.W. Woodmansee, and G.F.W. Haeniein, J Dairy Sci 54: 390-396. 1971. 
17) Block, R. J., J. A. Strkol, and J. K. Looslt, Arch Biochem Biophys 33: 353-363. 1951.

18) Patton, R.A., R.D. McCarthy, L.G. Keske, L.G. GRiel, Jr., and B.R. Baumgardt, J Dairy Sci 53 : 933-935. 1970.

19) NAder, C. J, and D. J. WALKer, Appl Microbiol 20;677-681. 1970.

\title{
反㫚胃内微生物による非蛋白態窒素化合物の利用におよぼす アミノ酸及び硫黄源の影響
}

\author{
高橋二三夫・龟高 正夫・神 立 誠* \\ 東京大学農学部栄養化学・家畜飼養学教室, 文京区 113
}

\begin{abstract}
著者らは前報において，反忽胃内微生物の尿素利用に よぼすナミ，酸の效果について報告した．本報告は前 に引き続き反罚胃内微生物の NPN 化合物の利用にお ぼす種々のアミノ酸および硫黄源の影響を検索するこ 定目的上し，前報上同㥞の培養条件下で培養安行い以 の結果を得た. 1. 完全フミノ酸混合物から種々のフ 八酸を除去した時の微生物蛋白質合成への影智では, 䂭つミノ酸除去区で蛋白質合成量は最少であった '<0.05)，2. N 源が疗素の場合における微生物蛋白質 成におよぼす 12 種のてミノ酸の添加效果を調へたた絬 , L-メチォニン添加区の蛋白質合成量江有意 $(\mathrm{P}<0.05)$ 界在：麻布㗂医科大学
\end{abstract}

に高かった。一方N源が完全アミ/酸混合物をたはカゼ インの場合には，Lーメチオニンの添加効果は諗められな かった. またLーメチオニンの添加効果は，その添加量 肪 $7 \mathrm{mg} /$ 試験管の時最大であり，それ以上に添加量安增 加しても，微生物蛋白買合成嶨か增加することはなかっ た. 3. 硫黄源としての L-メチオニンと硫酸塩の比較で は培垶開始後 6 時間の蛋白質合成量は，Lーメチオニン区 で有意 $(\mathrm{P}<0.05)$ に高加たた. 4. L-メ千オニンの添加 効果は，プロトソフの存在しない゙クテリアのみの場合

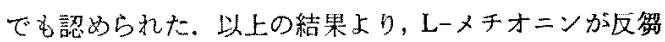
䡒内微坐物の蛋白質合成およびNPN 利用に関与する重 要な栄薣因子のーつであることが明らかとなった。 